Jurnal Care Vol .6, No.1,Tahun 2018

\title{
Perbedaan Metode Simulasi dan Self Directed Video Terhadap Pengetahuan,Sikap dan Ketrampilan Resusitasi Jantung Paru(RJP) Menggunakan I-Carrer Cardiac \\ Resuscitation Manekin Pada Siswa SMA Anggota Palang Merah remaja (PMR)
}

\author{
Wahyu Dini Metrikayanto, Muhammad Saifurrohman, Tony Suharsono \\ Program Magister Keperawatan Peminatan Gawat Darurat \\ Fakultas Kedokteran Universitas Brawijaya Malang \\ e-mail:wmetrik@yahoo.com
}

\begin{abstract}
Cardiac arrest can be happen in anywhere, anticipatable place (hospital) or unanticipatable place (out of hospital). People near by cardiac arrest victim has big role to give immadiately CPR. The purpose of this study was to identify the difference between simulation and self-directed video for knowledge, attitude, and skill of Cardiopulmonary Resuscitation (CPR) with I-CARRER Cardiac Resuscitation Manekin at High School student of Red Cross Youth (PMR). The study design was quasy experimental design with preposttest with control group. The location of this study was in High School of Malang (1, 3, 5 and 8). ). Simple random sampling was used as the sampling technique. The number of sample were 104 redcross youth member, hight school student. Data was analized by using Mann Whitney test. The result of Mann Whitney Test between knowledege posttest (simulation group) and knowledge posttest (self-directed video group) has $p$ value $=0,468$ ( $p>0,05)$, attitude posttest (simulation group) and attitude posttest (self-directed video group) has $p$ value $=0,739(p>0,05)$, and attitude posttest (simulation group) and attitude posttest (self-directed video group) has $p$ value $=0.089(p>0,05)$. The conclution of the study is both metode simulation and selfdircted video the knowledge, attitude, and skill of Cardiopulmonary Resuscitation (CPR) With ICARRER Cardiac Resuscitation Manekin among Redcross Youth Member, High School Student, but between simulation methode and self-directed video there was no differences to knowledge, attitude and skill of Cardiopulmonary Resuscitation (CPR) using I-Carrer Cardiac Resuscitation Mannequin at High School student of Red Cross Youth (PMR).
\end{abstract}

Keywordi: attitude; cardiopulmonary resuscitation (CPR; knowledge; skill; simulation; Self-Directed Video

\begin{abstract}
ABSTRAK
Henti jantung dapat terjadi di berbagai lokasi, baik yang tidak dapat diantisipasi (diluar rumah sakit) hingga yang dapat diantisipasi (misalkan; ruang perawatan intensif). Ketika terdapat korban henti jantung, orang yang berada di dekat korban tersebut memiliki peran yang sangat besar dalam melakukan RJP secara cepat. Tujuan dari penelitian ini adalah untuk mengidentifikasi perbedaan antara metode simulasi dan self directed video terhadap pengetahuan, sikap dan keterampilan Resusitasi Jantung Paru (RJP) menggunakan I-Carrer Cardiac Resuscitation Manekin pada siswa SMA anggota Palang Merah Remaja (PMR). Berdesain quasi eksperimanetal dengan pendekatan pre-post test with control group. Kelompok perlakuan diberikan intervensi Self-Directed Video pembelajaran RJP, kelompok kontrol
\end{abstract}


diberikan Intervensi Simulasi RJP. Penelitian di Sekolah Menengah Atas (SMA) 1, 3, 5 dan 8 Negeri Malang. Sampel adalah 104 siswa SMA anggota PMR. Analisa data menggunakan uji Mann Whitney. Hasil uji posttest pengetahuan (kelompok simulasi) dan posttest pengetahuan (kelompok self-directed video) memiliki nilai signifikansi $(p$ value)0,468 $(p>0,05)$, skor posttest sikap (kelompok simulasi) dan posttest sikap (kelompok self-directed video) memiliki nilai signifikansi $(p$ value $)=0,739$ ( $p>0,05)$, dan skor posttest keterampilan (kelompok simulasi) dan posttest keterampilan (kelompok self-directed video) memiliki nilai signifikansi ( $p$ value) $=$ $0.089(p>0,05)$. Disimpulkan metode simulasi dan self directed video berpengaruh terhadap pengetahuan, sikap dan keterampilan Resusitasi Jantung Paru (RJP) menggunakan I-Carrer Cardiac Resuscitation Manekin , akan tetapi antara metode simulasi dan self directed video tidak terdapat perbedaan terhadap pengetahuan, sikap dan keterampilan Resusitasi Jantung Paru (RJP) menggunakan I-Carrer Cardiac Resuscitation Manekin pada siswa SMA anggota Palang Merah Remaja (PMR).

Kata Kunci: Keterampilan; pengetahuan resusitasi jantung paru (RJP); sikap; simulasi; self directed Video

\section{PENDAHULUAN}

Henti jantung dapat terjadi di berbagai lokasi, baik yang tidak dapat diantisipasi (diluar rumah sakit) hingga yang dapat diantisipasi (misalkan; ruang perawatan intensif). Data menunjukkan bahwa $70 \%$ kasus OHCA terjadi di rumah dan hampir 90\% orang yang mengalami OHCA meninggal dunia. Ketika terdapat korban henti jantung, orang yang berada di dekat korban tersebut memiliki peran yang sangat besar dalam melakukan RJP secara cepat. RJP yang dilakukan khususnya pada beberapa menit pertama terjadinya henti jantung memberikan kontribusi kesempatan bertahan hidup 2 hingga 3 kali lipat (AHA, 2017). Sebaliknya, keterlambatan dalam melakukan RJP dapat menurunkan kesempatan hidup pada korban henti jantung
Rantai keberlangsungan hidup (Chain of Survival) merupakan model operasional yang digunakan dalam pemberian resusitasi. Model ini memiliki pengaruh dalam proses perawatan, sehingga dapat meningkatkan kelangsungan hidup pada beberapa komunitas yang telah diuji coba. Strategi dan intervensi pada rantai Chain of Survival bertujuan untuk meningkatkan kemampuan dalam mengenali adanya henti jantung serta meningkatkan ketepatan waktu dan kualitas pelayanan (Graham et al., 2015). Menurut Bhanji et al. (2010) diperlukan pendidikan yang bersumber dari bukti hasil penelitian serta strategi implementasi untuk dapat mengoptimalkan hubungan antar rantai Chain of Survival.Respon terhadap henti jantung yang efektif membutuhkan 
tindakan yang meliputi 5 rantai Chain of Survivals, yang mana tindakan tersebut secara langsung maupun tidak langsung dapat mempengaruhi hasil yang didapatkan. Bystander merupakan bagian dari masyarakat yang berada di garis terdepan dalam melaporkan kejadian dan memulai pertolongan. Terdapat 3 rantai pertama Chain of Survival (akses awal, RJP, dan defibrilasi) yang tergantung pada peran serta masyarakat pada mayoritas kasus henti jantung. Pada kondisi ini, seseorang perlu untuk melakukan bantuan hidup dasar, yaitu; menguhubungi EMS, memberikan RJP dan menggunakan automated external defibrillators (AED) jika tersedia (Graham et al., 2015). Di wilayah Indonesia, fasilitas defibrilator masih belum banyak tersedia di tempat umum seperti halnya diluar negeri. Sehingga, halhal yang perlu diperkuat dalam meningkatkan keberlangsungan hidup kasus OHCA adalah pada 2 rantai pertama keberlangsungan hidup (Chain of Survival)

Proses resusitasi yang dilakukan pada korban henti jantung masih belum maksimal. Menurut Wik et al. (2005), melaporkan bahwa selama resusitasi kasus OHCA, terdapat 33\% kompresi dada yang terlalu dangkal dan durasi yang diberikan hanya 48\% selama henti jantung. Data lain menunjukkan bahwa 15\% - 30\% korban henti jantung yang mendapatkan RJP sebelum petugas Emergency Medical System (EMS) datang (Abelle et al., 2008). Dalam penelitian yang dilakukan Taniguchi et al. (2012) yang berujudul 'Sikap Bystander Resusitasi Jantung Paru (RJP) Di Jepang Tahun 2010", menunjukkan bahwa hanya $15-30 \%$ partisipan yang bersedia melakukan kompresi dada dan ventilasi Mouth to Mouth dan 50-100\% yang bersedia melakukan kompresi dada tanpa ventilasi Mouth to Mouth.

Salah satu cara yang dapat dilakukan untuk memperkuat 2 rantai pertama Chain of Survival adalah meningkatkan jumlah penolong henti jantung di luar rumah sakit melalui edukasi tentang RJP pada masyarakat awam. Meningkatnya prosentase masyarakat yang mendapatkan pelatihan RJP merupakan bagian integral dari keseluruhan strategi dalam meningkatkan respon komunitas pada kasus henti jantung di luar rumah sakit. Sekolah memberikan akses yang baik menuju bagian besar komunitas. Data menunjukkan bahwa usia 5-14 tahun memiliki kesediaan mengikuti pelatihan RJP sebesar 97,4\%, sedangkan pada usia 15-19 tahun sebesar 76,5\% (Cave et al., 2011). Sehingga secara terus menerus, 
seluruh masyarakat dapat memperoleh pelatihan RJP.

Terdapat beberapa konsep edukasi dalam memberikan pelatihan resusitasi jantung paru berdasarkan American Heart Association (AHA). Diantara konsepkonsep tersebut antara lain: 1) melakukan penyederhanaan pada proses pelatihan, baik dari segi presentasi maupun isinya, 2) konsisten, yang berarti isi pelatihan dan ketrampilan yang didemonstrasikan seharusnya ditampikan dengan cara yang konsisten (misalkan dengan video), 3) berdasarkan tujuan, pelatihan yang dilakukan seharusnya menyertakan kemampuan pengetahuan, keterampilan dan efektif (Bhanji et al., 2010).

Edukasi yang dapat dilakukan untuk meningkatkan jumlah penolong OHCA adalah melalui simulasi maupun video (dalam hal ini adalah self-directed video). Program edukasi melalui simulasi dan self directed video memiliki kelebihan dan kekurangan tersendiri. Simulasi merupakah salah satu metode yang sering digunakan untuk melatih RJP pada masyarakat awam maupun tenaga professional. Metode pelatihan RJP dengan simulasi yang dibimbing langsung oleh pelatih bersertifikat merupakan satu- satunya metode pelatihan yang diakui di Indonesia saat ini. Selanjutnya, peserta pelatihan mendapatkan sertifikat formal sebagai peserta pelatihan. Kelebihan metode simulasi adalah lebih interaktif karena audience dapat bertanya secara langsung kepada fasilitator, namun membutuhkan waktu yang banyak dan tempat yang luas untuk melakukan metode ini. Sedangkan Self Directed Video adalah metode pembelajaran yang dapat memberdayakan masyarakat agar dapat belajar secara mandiri melalui tayangan video serta arahan-arahan yang disampaikan pada video edukasi tersebut. Kelebihan dari Self Directed Video adalah dapat digunakan oleh masyarakat dengan waktu yang bebas (tidak terikat) dan konsisten dari segi isi yang disampaikan. Self Directed Video yang terbukti dapat meningkatkan kemampuan dalam penanganan henti jantung dapat menjadi solusi dan inovasi dalam pelatihan RJP.

Self-Directed Video dapat menjadi salah satu metode yang efektif dan hemat terhadap sumber daya dalam mengedukasi orang awam tentang RJP. Dalam kondisi simulasi, orang awam yang diperlihatkan video Compression-only CPR, secara signifikan lebih cenderung melakukan resusitasi dibandingkan dengan mereka 
yang belum pernah melihat video pelatihan tersebut (Bobrow, et al., 2011). Self Directed Video yang terbukti dapat meningkatkan kemampuan dalam penanganan henti jantung dapat menjadi solusi dan inovasi dalam pelatihan RJP.

Upaya yang dapat dilakukan untuk menambah retensi pemahaman masyarakat ketika belajar RJP, diperlukan alat peraga yang mudah dijangkau dan ekonomis. I-CARRER Cardiac Resuscitation Menekin merupakan alat peraga yang digunakan untuk berlatih RJP. Alat ini didesain secara sederhana dengan bentuk setengah badan orang dewasa dengan ketebalan $8 \mathrm{~cm}$. Selain itu, pada alat I-CARRER Cardiac Resuscitation Menekin terdapat lampu indikator yang menunjukkan ketepatan kedalaman pada saat melakukan pijat jantung. Kelebihan yang diperoleh dari alat peraga RJP "I-CARRER Cardiac Resuscitation Menekin" adalah alat yang sederhana, bahan baku yang ekonomis namun tidak mengurangi esensi dari pembelajaran RJP.

Dari data sebelumnya, sekolah dapat memberikan akses yang luar biasa menuju bagian besar komunitas. Pada Sekolah Menengah Atas (SMA), terdapat sebuah kegiatan ekstrakulikuler yang disebut
Palang Merah Remaja (PMR). PMR adalah sebuah kegiatan yang selalu menanamkan sikap tanggung jawab, kepedulian sosial yang tinggi, dan memiliki rasa kerja sama yang tinggi (Sukmawati, 2016). Usia anggota PMR pada siswa Sekolah Menengah Atas (SMA) umumnya antara 16-18 tahun. Pada penelitian yang berjudul 'Seberapa efektif orang muda dapat melakukan resusitasi jantung paru (RJP) tanpa pelatihan" yang dilakukan oleh Beard et al. (2015) menunjukkan bahwa anak usia 11 tahun dapat melakukan arahan dari dispatcher (operator EMS) untuk melakukan RJP dengan kecepatan dan kedalaman kompresi dada yang sesuai. Hal ini menunjukkan bahwa siswa SMA anggota PMR yang berusia 16-18 sudah memenuhi kriteria dalam melakukan RJP secara efektif. Ditambah lagi dengan jiwa kemanusiaan yang sudah dimiliki siswa PMR tersebut dapat menjadi modal utama dalam melakukan bantuan RJP saat ada korban yang membutuhkan.

Penelitian yang bertujuan untuk membedakan antara metode simulasi dan self-directed video yang menggunakan alat peraga I-Carrer Cardiac Resuscitation Manekin belum pernah dilakukan di anggota PMR di SMA Kota Malang. Dengan mengetahui manfaat serta 
kelebihan masing-masing dari metode yang gunakan dalam penelitian ini dapat menjadi solusi untuk proses pelatihan RJP selanjutnya. Sehingga upaya meningkatkan jumlah bystander RJP dapat lebih cepat dan efisien.

Tujuan umum dari penelitian ini adalah mengidentifikasi perbedaan antara metode simulasi dan self directed video terhadap pengetahuan, sikap dan keterampilan Resusitasi Jantung Paru (RJP) menggunakan I-Carrer Cardiac Resuscitation Manekin pada siswa SMA anggota Palang Merah Remaja (PMR).

\section{METODE PENELITIAN}

Penelitian ini menggunakan desain quasi eksperimanetal dengan pendekatan pre-post test with control group.Penelitian ini dilakukan di Sekolah Menengah Atas (SMA) 1, 3, 5 dan 8 Negeri Malang. Kegiatan pengambilan data dalam penelitian ini telah dilakukan pada bulan Oktober November 2017. Kelompok perlakuan dan kelompok kontrol dilakukan di SMA yang berbeda dengan jumlah sampel 104 .

Alat yang digunakan dalam penelitian ini ialah lembar kuisioner dan observasi. Pelaksanaan penelitian dilakukan dengan mengidentifikasi daftar mahasiswa yang memenuhi kriteria inklusi sampel penelitian. Tahap pertama peneliti memberikan penjelasan tentang tujuan dan gambaran umum penelitian kepada responden, selanjutnya responden mengisi lembar persetujuan (informed concent) sebagai responden penelitian. Tahap kedua responden mengisi lembar pre-test untuk melihat kemampuan pengetahuan dan sikap RJP. Pada tahap pre test ini, responden juga diminta untuk mempraktekkan tindakan RJP pada manikin yang disediakan berdasarkan skenario kasus yang disiapkan sebelumnya. Pada saat responden melaksanakan tindakan RJP, peneliti menilai prosedur tindakan dan kualitas RJP pada lembar observasi.

Tahap ketiga adalah memberikan intervensi pada masing-masing kelompok, yaitu penayangan self-directed video dan simulasi. Kedua kelompok tersebut mendapatkan intervensi selama 60 menit di dua ruang/kelas yang berbeda.

Selanjutnya tahap keempat, yaitu tahap post test. Pada tahapan ini responden diminta untuk mengisi lembar kuisioner untuk menilai pengetahuan dan sikap. Setelah selesai mengisi lembar kuisioner, responden diminta untuk mempraktekkan 
prosedur RJP sesuai dengan scenario yang telah disiapkan untuk menilai kemampuan keterampilan. Tahap terakhir adalah melakukan analisis data univariat dan bivariat.
Persetujuan etik telah didapatkan dari komisi etik penelitian kesehatan di Fakultas Kedokteran Universitas Brawijaya Malang dengan memperhatikan respect for person, beneficence \& non maleficence dan justice.

\section{HASIL}

Tabel 1. Karakteristik Responden

\begin{tabular}{|c|c|c|}
\hline Variabel & $\mathrm{N}$ & $\%$ \\
\hline \multicolumn{3}{|l|}{ Jenis Kelamin } \\
\hline Laki-laki & 20 & $24 \%$ \\
\hline Perempuan & 84 & $76 \%$ \\
\hline \multicolumn{3}{|l|}{ Usia } \\
\hline 14 tahun & 2 & $1,9 \%$ \\
\hline 15 tahun & 61 & $58,7 \%$ \\
\hline 16 tahun & 37 & $35,6 \%$ \\
\hline 17 tahun & 4 & $3,8 \%$ \\
\hline \multicolumn{3}{|c|}{$\begin{array}{l}\text { Menemukan orang yang sedang mengalami henti } \\
\text { jantung }\end{array}$} \\
\hline Belum pernah & 96 & $92,3 \%$ \\
\hline Pernah & 8 & $7,7 \%$ \\
\hline \multicolumn{3}{|c|}{$\begin{array}{l}\text { Tindakan yang dilakukan ketika menemukan orang } \\
\text { henti jantung }\left(^{*} \text { bagi responden yang pernah menemukan) }\right.\end{array}$} \\
\hline Memanggil ambulans & 1 & $12,5 \%$ \\
\hline Meminta bantuan masyarakat sekitar & 5 & $62,5 \%$ \\
\hline Tidak melakukan apa-apa & 2 & $25 \%$ \\
\hline \multicolumn{3}{|c|}{$\begin{array}{l}\text { Memiliki anggota keluarga/kerabat yang menderita } \\
\text { sakit jantung }\end{array}$} \\
\hline $\mathrm{Ya}$ & 75 & $72,1 \%$ \\
\hline Tidak & 29 & $26,9 \%$ \\
\hline
\end{tabular}

Sumber Data Primer (2017)

Tabel 2 hasil uji Mann Whitney antara skor posttest pengetahuan (kelompok simulasi) dan posttest pengetahuan (kelompok selfdirected video) memiliki nilai signifikansi ( $p$ value $)=0,468(p>0,05)$. Hal ini berarti tidak terdapat perbedaan antara skor posttest pengetahuan (kelompok simulasi) dan posttest pengetahuan (kelompok selfdirected video) pelatihan RJP menggunakan I-CARRER Cardiac Resuscitation Manekin. 
Tabel 2 Perbedaan Skor Pengetahuan RJP antara Kelompok Simulasi dan Self-Directed Video Menggunakan I-CARRER Cardiac Resuscitation Menekin

\begin{tabular}{lccc}
\hline Pengetahuan & Mean(SD) & $95 \%$ CI & $p$ \\
\hline Pretest & & & 0,696 \\
Simulasi & $17.10(0,172)$ & $16,75-17.44$ & \\
Self-Directed & $17.00(0,213)$ & $16,57-17.43$ & \\
$\quad$ Video & & & \\
Posttest & & & 0,468 \\
$\quad$ Simulasi & $18.88(0.105)$ & $18.67-19.10$ & \\
$\quad$ Self-Directed & $18.98(0.112)$ & $18.76-19.20$ & \\
$\quad$ Video & & & \\
\hline
\end{tabular}

Uji Mann Whitney: Posttes Simulasi vs Posttest Video $=0,468(\not>0,05)$

Ket: $\mathrm{SD}=$ Standar Deviasi; $\mathrm{CI}=$ Confidence Interval

Tabel 3 Perbedaan Skor Sikap RJP antara Kelompok Simulasi dan Self-Directed Video Menggunakan I-CARRER Cardiac Resuscitation Menekin

\begin{tabular}{lccc}
\hline \multicolumn{1}{c}{ Sikap } & Mean(SD) & $95 \%$ CI & $p$ \\
\hline Pretest & & & 0.142 \\
Simulasi & $13.42(0.391)$ & $12.64-14.21$ & \\
$\quad$ Self-Directed & $12.62(0,419)$ & $11.77-13.46$ & \\
$\quad$ Video & & & \\
Posttest & & & 0.739 \\
$\quad$ Simulasi & $15.23(0.219)$ & $14.79-15.67$ & \\
$\quad$ Self-Directed & $15.15(0.242)$ & $14.67-15.64$ & \\
$\quad$ Video & & & \\
\hline
\end{tabular}

Uji Mann Whitney: Posttes Simulasi vs Posttest Video $=0,739(p>0,05)$

Ket: $\mathrm{SD}=$ Standar Deviasi; $\mathrm{CI}=$ Confidence Interval

Tabel 4 Perbedaan Keterampilan RJP antara Kelompok Simulasi dan Self-Directed Video Menggunakan I-CARRER Cardiac Resuscitation Menekin

\begin{tabular}{lccc}
\hline Keterampilan & Mean(SD) & $95 \%$ CI & $p$ \\
\hline Pretest & & & 0,226 \\
$\quad$ Simulasi & $11.77(0.085)$ & $11.60-11.94$ & \\
$\quad$ Self-Directed & $11.46(0.152)$ & $11.16-11.77$ & \\
$\quad$ Video & & & \\
Posttest & & & 0.089 \\
$\quad$ Simulasi & $15.75(0.061)$ & $15.63-15.87$ & \\
$\quad$ Self-Directed & $15.87(0.055)$ & $15.75-15.98$ & \\
$\quad$ Video & & & \\
\hline Uji Mann Whitney: Posttes Simulasivs Posttest Video $=0,515(p>0,05)$
\end{tabular}

Uji Mann Whitney: Posttes Simulasi vs Posttest Video $=0,515(p>0,05)$

Ket: $\mathrm{SD}=$ Standar Deviasi; $\mathrm{CI}=$ Confidence Interval 
Tabel 3 hasil uji Mann Whitney antara skor posttest sikap (kelompok simulasi) dan posttest sikap (kelompok self-directed video) memiliki nilai signifikansi ( $p$ value) $=0,739$ $(p>0,05)$. Hal ini berarti tidak terdapat perbedaan antara skor posttest sikap (kelompok simulasi) dan posttest sikap (kelompok self-directed video) pelatihan RJP melalui Self-Directed Video menggunakan I-CARRER Cardiac Resuscitation Manekin.

\section{PEMBAHASAN}

Analisis perbedaan antara metode simulasi dan self directed video terhadap pengetahuan, sikap dan keterampilan Resusitasi Jantung Paru (RJP) menggunakan I-Carrer Cardiac Resuscitation Manekin pada siswa SMA anggota Palang Merah Remaja (PMR).

Hasil uji Mann Whitney untuk melihat perbedaan dari kedua model pelatihan (simulasi dan self-directed video) diperoleh nilai $p=0,468(p>0,05)$. Hasil uji Mann Whitney tersebut menunjukkan bahwa tidak ada perbedaan peningkatan pengetahuan, sikap dan keterampilan RJP antara simulasi dan self-directed video menggunakan I-CARRER Cardiac Resuscitation Menekin pada siswa SMA anggota PMR.Pendekatan pembelajaran dengan menggunakan self-directed video dalam pelatihan RJP merupakah bukan hal yang baru. Pada artikel sistematik riview yang ditulis oleh Vaillancourt, Stiell, dan Wells (2008) mencatat bukti bahwa siswa yang mengikuti pelatihan RJP menggunkan self-directed video dibandingkan dengan pembelajaran CPR di kelas secara tradisional menunjukkan hasil yang sama baiknya. Pada penelitian lain juga menunjukkan hasil yang juga sama, yaitu penelitian yang dilakukan oleh Lynch et al.. Pada tahun 2005. Lynch et al. (2005) menginvestigasi pengaruh orang dewasa (usia 40-70 tahun) yang mengikuti pelatihan RJP selama paling tidak 5 tahun. Masing-masing responden diacak untuk masuk dalam kelompok kontrol (pelatihan tradisional dengan instruktur atau program self instruction) Siswa yang berada pada program self instruction mendapatkan seperangkat media belajar berupa video dengan durasi 22 menit, Mini Anne manikin, dan peralatan elektronik untuk mengecek kecepatan dan kedalaman kompresi serta ketepatan posisi kompresi. Lynch et al. menyimpulkan bahwa pelatihan dengan menggunkan video selfinstruction dibandingkan dengan pelatihan tradisional menunjukkan hasil yang sama baiknya.Dari hasil uji Mann Whitney yang telah dijelaskan sebelumnya menunjukkan 
bahwa pelatihan RJP dengan menggunakan I-CARRER Cardiac Resuscitation Menekin melalui Simulasi dan Self-Directed Video keduanya berhasil dalam meningkatkan pengetahuan siswa SMA anggota PMR. Self-directed video dapat dijadikan alternatif dalam memberikan pelatihan RJP. Hal ini disebabkan karena Self-directed video memiliki beberapa kelebihan dibandingkan dengan pelatihan simulasi (tradisional). Kelebihan dari Self Directed Video adalah dapat digunakan oleh masyarakat dengan waktu yang bebas (tidak terikat) dan konsisten dari segi isi yang disampaikan. Selfi-directed video yang terbukti dapat meningkatkan kemampuan dalam penanganan henti jantung dapat menjadi solusi dan inovasi dalam pelatihan RJP. Self-Directed Video dapat menjadi salah satu metode yang efektif dan hemat terhadap sumber daya dalam mengedukasi orang awam tentang RJP. Dalam kondisi simulasi, orang awam yang diperlihatkan video Compression-only CPR, secara signifikan lebih cenderung melakukan resusitasi dibandingkan dengan mereka yang belum pernah melihat video pelatihan tersebut (Bobrow, et al., 2011). Self Directed Video yang terbukti dapat meningkatkan kemampuan dalam penanganan henti jantung dapat menjadi solusi dan inovasi dalam pelatihan
RJP.Menurut Nikandish et al. (2005) videobased CPR Self-Instruction (VSI) dapat digunakan sebagai salah satu metode alternative dalam setting pendidikan karena mempunyai beberapa keuntungan antara lain sebagai pilihan dalam pemberian pelatihan bantuan hidup dasar yang dibatasi oleh waktu, waktu yang digunakan oleh pelatih lebih fleksibel, mengurangi kecemasan dari peserta untuk berlatih keterampilan RJP dihadapan pelatih, waktu yang digunakan untuk mempraktekkan band-only CPR lebih memadai dan dapat digunakan ketika mengalami kekurangan instruktur dalam pelaksanaan pelatihan RJP.

Pelatihan RJP melalui simulasi dan selfdirected video secara terperinci dapat diketahui kelebihan masing-masing dari hasil uji statistik setiap pertanyaan. Pada Tabel 4 tentang perbedaan pengetahuan RJP (menjawab pertanyaan dengan benar) pada kelompok simulasi dan self-directed video, diketahui bahwa simulasi lebih bemakna dalam meningkatkan pengetahuan tentang alur RJP Handsonly, sifat henti jantung dan prinsip RJP handsonly dibandingkan dengan selfdirected video. Sedangkan peningkatan pengetahuan tentang manfaat RJP lebih bermakna pada self-directed video 
dibandingkan dengan simulasi.Self-directed video lebih bermakna dalam meningkatkan sikap responden dalam soal kasus kesediaan melakukan pijat jantung dan nafas buatan, kesediaan melakukan pertolongan pada kasus 1 (ayah/ibu), kesediaan melakukan pertolongan pada kasus 2 (paman) dan kesediaan melakukan pertolongan pada kasus 3 (anak kecil). Selfdirected video lebih bermakna dalam meningkatkan keterampilan responden dalam berteriak untuk mendapatkan pertolongan dan mengaktifkan sistem tanggapan gawat darurat. Sedangkan pada poin observasi yang lain (memeriksa keamanan lingkungan, memulai kompresi dada, melanjutkan kompresi dada hingga bantuan datang) memiliki makna dalam peningkatan keterampilan poin tersebut. Menurut Wik et al. (2005), melaporkan bahwa selama resusitasi kasus OHCA, terdapat 33\% kompresi dada yang terlalu dangkal dan durasi yang diberikan hanya 48\% selama henti jantung. Data lain menunjukkan bahwa 15\% - 30\% korban henti jantung yang mendapatkan RJP sebelum petugas Emergency Medical System (EMS) datang (Abelle et al., 2008). Sedangkan di Indonesia saat ini masih belum ada data mengenai jumlah bystander RJP maupun kualitas pemberian RJP. Pada penelitian ini pelatihan RJP dilakukan dengan dua metode, yaitu simulasi dan self-directed video. Dari kedua metode tersebut masing-masing terbukti dapat meningkatan tiga penilaian variabel (pengetahuan, sikap dan keterampilan). Hal ini diketahui dari nilai $p$ antara pretest dan posttes menunjukkan 0,000 $(\mathrm{p}<0,05)$. Akan tetapi yang perlu diperhatikan adalah penilaian pada variabel keterampilan masih berkaitan dengan alur prosedur handsonly RJP, belum melihat kualitas RJP yang diterapkan. Namun hal ini dapat menjadi barometer awal bahwa simulasi maupun self-directed video mampu meningkatkan pengetahuan, sikap dan keterampilan dalam melakukan RJP. Dua metode pelatihan RJP (simulasi dan self-directed video) memiliki keunikan masing-masing. Pada metode self-directed video, peserta pelatihan dapat belajar secara mandiri, hal ini menjadi sisi positif bahwa metode pelatihan ini dapat dilakukan dimana saja dan kapan saja. Akan tetapi ketika peserta belajar secara mandiri, kualitas keterampilan yang diperoleh tidak dapat diidentifikasi. Sehingga untuk menjembatani hal tersebut, perlu adanya modifikasi dalam penggunaan metode pelatihan RJP. Modifikasi dapat diterapkan disini antara lain; 1) mentor atau pelatih yang mengevaluasi khususnya dalam hal keterampilan. Namun 
sebaliknya dengan metode simulasi, metode ini kurang fleksibel dan membutuhkan mentor atau pelatih, akan tetapi pelatih tersebut dapat langsung memberikan umpan balik berkaitan dengan keterampilan peserta.

\section{KESIMPULAN}

Secara statistik antara metode simulasi dan self directed video terhadap pengetahuan, sikap dan keterampilan RJP menggunakan I-Carrer Cardiac Resuscitation Manekin tidak terdapat perbedaan, akan tetapi dari analisis pertanyaan pada masing-masing variabel, dapat diketahui bahwa selfdirected video lebih baik dalam meningkatkan sikap peserta tentang RJP, self-directed video lebih baik dalam meningkatkan keterampilan dalam memeriksa respon korban dan mencari pertolongan dan pengaktifan EMS (Emergency Medical Service).

Direkomendasikan RPJ menggunakan ICARRER Cardiac Resuscitation Menekin melalui Self Directed Video dapat menjadi metode yang dapat diterapkan di lingkungan SMA anggota PMR untuk meningkatkan jumlah bystander pada jadwal latihan rutin ekstrakulikuler PMR.

\section{REFERENSI}

AHA. (2017). CPR Facts and Stats. Diakses dari: http://cpr.heart.org/ AHAECC/CPRAndECC/Abou tCPRFirstAid/CPRFactsAndSta ts/UCM_475748_CPR-Factsand-Stats.jsp, pada tanggal 15 Januari 2017 pada pukul 13.16 WIB

Bhanji, F., Mancini, M. E., Sinz, E., Rodgers, D. L., Mcneil, M. A., Hoadley, T. A., Meeks, R. A., Hamilton, M. F., Meaney, P. A., Hunt, E. A., Nadkarni, V. M. \& Hazinski, M. F. (2010). Part 16: Education, Implementation, and Teams. 2010 American Heart Association Guidelines for Cardiopulmonary Resuscitation and Emergency Cardiovascular Care, 122, S920-S933.

Bobrow B, Vadeboncoeur T, Spaite DW, et al. (2011). The effectiveness of ultrabrief and brief educational videos for training lay responders in hands-only cardiopulmonary resuscitation: implications for the future of citizen cardiopulmonary resuscitation training. Circ Cardiovasc Qual

Cave, D. M., Aufderheide, T. P., Beeson, J., Ellison, A., Gregory, A., Hazinski, M. F., Hiratzka, L. F., Lurie, K. G., Morrison, L. J., Mosesso, V. N., Nadkarni, V., Potts, J., Samson, R. A., Sayre, M. R. \& Schexnayder, S. M. (2011). Importance and Implementation of Training in Cardiopulmonary Resuscitation and Automated External Defibrillation in Schools. A Science Advisory From the American Heart Association, 123, 691-706. 
Gandhi, S., D, Mythili, \& A, Thirumoorthy. (2015). Nursing students perceptions about traditional and innovative teaching strategies - a pilot study. Journal of Krishna Institute of Medical Sciences University, 4, 123-129.

Nikandish R, Askaree AR and Karamad T. (2005). Comparasion of basic life support (BLS) video selfinstructional system and traditional BLS training in first year nursing student. Journal of Medical Education. Vol 7 No 1
Taniguchi, T., Sato, K., Fujita, T., Okajima, M. \& Takamura, M. (2012). Attitudes to bystander cardiopulmonary resuscitation in Japan in 2010. Circ J, 76, 1130-5, diakses dari https://www.ncbi. nlm.nih.gov/pubmed/22382380 pada tanggal 27 Februari 2017

Wik, L., Kramer-Johansen, J., Myklebust, H., Sorebo, H., Svensson, L., Fellows, B. \& Steen, P. A. (2005). Quality of cardiopulmonary resuscitation during out-ofhospital cardiac arrest. $J A M A$, 293, 299-304, diakses pada tanggal 23 Februari 2017 